\title{
The Influence of Online Customer Behavior and Brand Trust on Online Purchase Interest
}

\author{
Khilyatin Ikhsani ${ }^{1}$, Agung Hudaya ${ }^{2}$ \\ \{khilyatin.dyah@undira.ac.id ${ }^{1}$,agung24@mercubuana.ac.id $\left.{ }^{2}\right\}$ \\ Management Departement, Faculty of Bisnis and Social Science, Universitas Dian Nusantara, Jakarta, \\ Indonesia ${ }^{1}$, Management Departement Faculty of Economics and Business, Universitas Mercu Buana, \\ Jakarta, Indonesia ${ }^{2}$
}

\begin{abstract}
This research aims to examine the effect of online consumer behavior on online purchase interest and brand trust on online purchase interest. The objects are physical stores which also have online shops. This study used linear regression analysis with Smart PLS 3.0. The data collection method is using nonprobability sampling. The population studied was individuals who had shopped at physical stores as well as shopping online. The samples were 100 respondents. The results of the study show that online consumer behavior has a positive and significant effect on purchase intention and brand trust has a positive and significant.
\end{abstract}

Keywords: Online Purchase Interest, Online Consumer Behavior, Brand Trust, Hypermart

\section{Introduction}

The rise of direct online shopping activities has resulted many terms, for example COD (cash on delivery) for cash payments on the spot according to the seller's agreement with the buyer, testimonials are intended as comments on other products and services provided by online sellers to customers who have transacted to give a review in the column comments as promotional material for other potential buyers, recommended sellers or trusted sellers, the term is used to indicate that the online seller is a seller who is trusted by many online buyers, both because the quality of the goods sold and the services provided are considered satisfactory to the buyer, starting from reply to chat Regarding the product and the speed at which the goods are delivered to buyer and neatness of the delivery package [1]. 


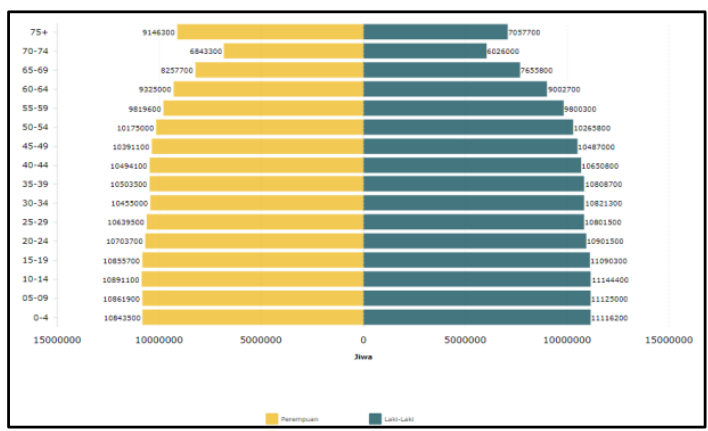

Figure 1.Graph of Indonesia's Population by Age Group (2045)

Source: katadata (2018)

Based on figure 1. in 2045 or 100 years since Indonesia's independence, it is predicted that the vulnerable age group 15-19 and 20-24 have a large population. Demographic capital is an asset for the development of the Indonesian economy, especially for the retail industry. With a large demographic for vulnerable productive age, it is a guarantee for the continued growth of public consumption [2].

Consumption growth is a prerequisite for the development of the retail industry in order to get the expected results, namely increasing profits. However, demographic assets and the widespread use of the internet to convey product information to massive sales promotions are not really utilized by the retail industry in general in increasing the number of sales. Instead of making a profit due to the established fundamentals of retail companies in selling consumer products, they get the opposite result, namely continuous losses or declining growth [3].

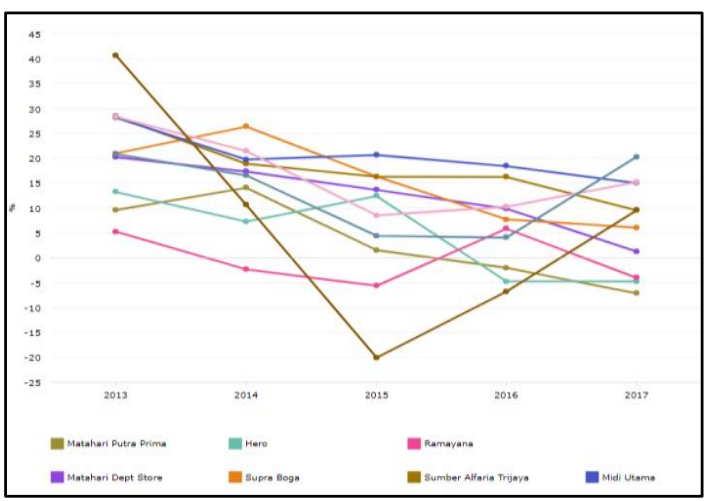

Figure 2. Chart of Sales Growth of 10 Retail Issuers Source: katadata (2018) 
Based on the financial reports of issuers that have been published by Katadata, it shows that 10 companies in the sector of retail in 2017 experienced a slowdown in sales/revenue growth that compared with 2013. The highest decline in sales was recorded by ECII, reached more than 3,100 or only $9.55 \%$ in 2017 compared with $40.69 \%$ in 2013. Meanwhile, ACES experienced the lowest decline in sales, namely only 53 or only $20.31 \%$ compared with $20.85 \%$ in 2013 . In fact three retail companies, such as RALS, PT Hero Supermarket Tbk and LPPF experienced a decline in sales last year from previous years. The total sales of the 10 retail companies below in 2017 only raised $6.41 \%$ from the previous years, in 2013 it was able to record the growth more than $21 \%$ compared with the previous years.

Meanwhile, the phenomenon of online shopping is more due to changes in people's behavior with the influence of changes in information technology and telecommunications which are increasingly developing rapidly, plus internet access with wide area coverage at lower costs. Changes in online shopping behavior should be able to be predicted by large retail industries in order to increase sales and profits by adopting developments in information technology and telecommunications [4]

Table 1. Sales Growth of PT. Matahari Putra Prima Tbk Year 2013 - 2017

\begin{tabular}{cc}
\hline Year & Percentage of Growth \\
\hline 2013 & $9.61 \%$ \\
2014 & $14.08 \%$ \\
2015 & $1.56 \%$ \\
2016 & $-1.99 \%$ \\
2017 & $-7.13 \%$ \\
\hline
\end{tabular}

Hypermart is a retail store owned by PT. Matahari Putra Prima Tbk was founded in 2004, had experienced significant growth in 2014 , namely $14.08 \%$, but after that it continued to decline. Apart from DKI Jakarta, Tangerang City is a city that has the highest number of Hypermart stores in a city, based on table 1 showed that after 2014 Hypermart sales growth tended to decline. This trend can be seen through the sale of Hypermart stores in Tangerang City.

The potential for online buyers that continues to grow as a result of individual behavior in using the internet is balanced with customer satisfaction with the physical store that Hypermart has since 2004 is a good capital in creating business diversification opportunities, namely online stores in addition to existing physical stores. 


\begin{tabular}{|lll|}
\hline \multicolumn{2}{|c|}{ TBI 2019 } & \\
\hline Transmart Carrefour & $33.4 \%$ & TOP \\
Hypermart & $19.6 \%$ & TOP \\
Giant & $19.2 \%$ & TOP \\
Lotte Mart & $2.3 \%$ & \\
& & \\
\hline
\end{tabular}

Figure 3. Top Brand 2018 Retail Category

Source: https://www.topbrand-award.com/top-brand-index/?tbi_find=hypermart, accessed 2020

As second rank on a survey conducted by Top Brand Award and the Frontier Consulting Group with category of retail in 2018. With this Top Brand Award, this gives an indication of consumer confidence in Hypermart brand.

\section{Literature Review}

\subsection{Online Purchase Interest}

Purchase interest according to Kotler and Keller is a stage of selection by consumers on a collection of brands or products that they like and also build interest in buying the product they really want [5]. In purchase interest stage, consumers will be involved in 5 sub-decision making, namely the choice of brand, seller, amount, time and method of payment that the consumer wants.

Ahn and Back categorized purchase interest as part of behavioral intention [6]. It can be seen that consumer purchase interest in general consists of:

1) Favorable behavioral intention, the attitude shown by consumers as if they feel quite close to the producer / company. Described the condition of consumers who are close to producers showing consumer behavior that appreciates producers, expresses siding with producers, high purchasing, and deals with the price offeed.

2) Unfavorable behavioral intentions, changes in behavior aimed at consumers because the performance produced by producers / companies is considered not meeting the expectations of consumers. Dissatisfied consumer behavior is in the form of taking action not to buy / use at all to reduce the purchase of products from producers that consumers mean.

\subsection{Online Consumer Behavior}

Mamang and Sopiah define consumer behavior as actions that are directly involved in obtaining, consuming, and ending products or services, including the processes that precede and follow these actions [7]. Consumer behavior according to Kottler and Keller is the science that studies how individuals, groups, and organizations to make a choice, to buy, to use, and to spend goods, services, ideas, results of thoughts, or experiences to satisfy their need and desire [8]. 
According to Hayden Noel, behavior of consumer is behavior of individual regarding to the activities (purchase and the use of goods and services) and how the activities can affect individual life. The activity in question focuses on consumption activities that are carried out to spend goods and services in meeting the needs of consumers [9].

One of the external factors that drives changes in consumer behavior in decision making is technology. Currently technology plays an important role in consumer decision making in purchasing. Online nowadays has become terms for activities and individual behavior who active in cyberspace by using smartphones, computers, and other tools which are connected to internet. Lee and Kim online behavior of consumer shows consumer engagement behavior in purchasing products online [10].

Based on research by Cazan et al. stated that the tendency of online consumer behavior is influenced by several aspects, including [11]:

1) Computer anxienty, the aspect of individual assessment of difficulties in using the internet.

2) Attitude to the internet, an aspect of assessing individual behavior towards internet use in influencing daily life.

3) Computer self efficacy, the individual's ability to use computer equipment and technology in everyday life.

Based on the research conducted by Cazan et al computer anxienty, computer self-efficacy, as a whole forms an attitude to the internet. Attitude to the internet or online behavior encourages consumer using internet to support the activities based on the experience that consumers have in the digital world and the internet [11].

\subsection{Brand Trust}

According to The American Marketing Association (AMA) a brand is a name, sign, symbol, term, or design or combination of all that aims to identify good and service of a seller or a collection of sellers to differentiate between one another in market competition.

A brand is more than a product, because it has dimensions that are able to distinguish the same similar product designs from other competitors. In other words, a brand functions as an identity that differentiates between products, be it similar or different products [12].

Brand has important role for consumers avoiding risks which are considered important for consumer buying or consuming the product, risks from brands include:

1) Functional risk, the risk in the form of product performance not as expected.

2) Physical riskthat is, the risk that the physical product will endanger the health or life of the user.

3) Financial risk, that is, the product price does not exceed the fair price.

4) Social risk, namely the product does not embarrass users.

5) Psychological risk, namely the product is able to affect the mental / mental condition of the user

6) Time risk, namely product defects in the form of inconsistencies in the duration of use based on the product's recommended age.

Brands that have been selected by consumers for consumption have the advantage of brand trust in both the product and the producer. Brand trust according to Keller brand trust is something that is believed and stored as a consumer's memory because it has an important meaning. 
Priansa says there are several dimensions that can be used to measure consumer trust, namely

1) System Orientation, the amount of consumer confidence in the company or product can be measured by the amount of their trust in the system used by the company. 2 .

2) Reputation, When consumers make a transaction with a company, they will consider the company's reputation where when consumers feel a company has a bad reputation they are reluctant to use products or services from that company.

3) Perceived Risk The amount of consumer perception about risk can affect the amount of their trust in the company so that when they want to use the company's products or services, consumers often assume that there is a high risk.

Based on the research formulation, research objectives, literature review, previous research and research rood map, the framework for this research for internal research is as shown in Figure 2 below.

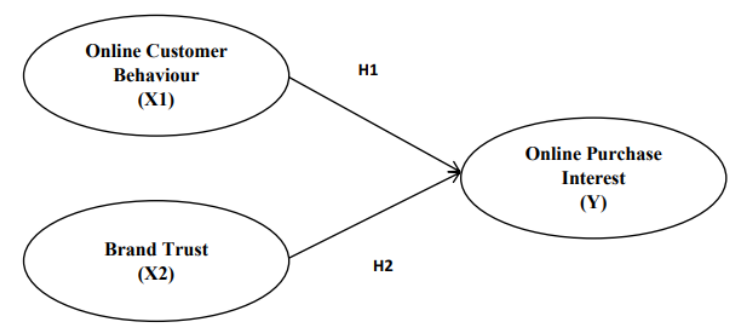

Figure 4. Framework for thinking

\section{Hypothesis}

Based on the research objectives, the research hypothesis is as follows:

1) H1: Online consumer behavior has positive and significant effect on Online Purchase Interest in Hypermart Supermarket Tangerang City.

2) H2: Brand trust has positive and significant effect on Online Purchase Interest in Hypermart Supermarket Tangerang City.

\section{Methods}

\subsection{Research Objects and Instruments}

The population in this study is consumers who have shopped online and have also shopped physically at the Hypermart in the Tangerang City area. The sample of this study was 100 respondents, with the number of online visitors to Matahari Mall as many as 2,784,900, using the Slovin formula obtained a sample of 100 people. The research was conducted for 6 months, from January to June 2020. The instrument used was a questionnaire using a Likert scale with a score of 1-5 which was expressed from the most negative, neutral to the most positive. 


\subsection{Methods and Analysis Tools}

The method of analysis of this research is quantitative method. Quantitative research is based on data in form of numbers. The data in the form of numbers in quantitative research concerning the object of research that examines certain variables and analysis tools with multiple linear regression followed by analysis of determination (RSquare), partial hypothesis testing ( $t$ test) and simultaneous ( $F$ test) with alpha 10 percent $(0,1)$. Before being analyzed, first the instrument test (questionnaire) was tested with validity and reliability as well as classical assumptions, used with SMART PLS 3.0.

The regression model is a statistical model that purposes to analyze the effect of various independent variables on one dependent variable [14]. Online consumer behavior and brand trust as the independent variable, purchasing decisions as the dependent variable. The multiple linear regression analysis method can be described as in Figure 3.1 above with the equation formula:

$$
\mathrm{Y}=\alpha+\beta 1 \mathrm{X} 1+\beta 2 \mathrm{X} 2+\mathrm{e} .
$$

\section{Result and Discussion}

\subsection{Result}

The result of Validity and Reliability test as follow:

Table 2. Results of Validity and Reliability Test

\begin{tabular}{lcccc}
\hline \multicolumn{1}{c}{ Construct } & Items & Loadings & $\begin{array}{c}\text { Average Variance } \\
\text { Extracted (AVE) }\end{array}$ & $\begin{array}{c}\text { Composite } \\
\text { Reliability }\end{array}$ \\
\hline Online Customer Behavior & $\mathbf{X 1 . 1}$ & 0.803 & $\mathbf{0 . 7 8 6}$ & $\mathbf{0 . 9 1 7}$ \\
& $\mathbf{X 1 . 2}$ & 0.933 & & \\
Brand Trust & $\mathbf{X 1 . 3}$ & 0.918 & & \\
& $\mathbf{X 2 . 1}$ & 0.899 & $\mathbf{0 . 7 2 4}$ & $\mathbf{0 . 7 2 4}$ \\
Online Purchase Intention & $\mathbf{X 2 . 2}$ & 0.916 & & \\
& $\mathbf{X 2 . 3}$ & 0.725 & & $\mathbf{0 . 8 7 9}$ \\
& $\mathbf{Y 1 . 1}$ & 0.946 & $\mathbf{0 . 8 7 9}$ & \\
\hline
\end{tabular}

Source: Primary data, processed 2020

From the table 2 above showed that all the constructs have composite reliability value more than 0.70 . So it can be explained that construct has good reliability. 
Table 3. Result of AVE

\begin{tabular}{lc}
\hline \multicolumn{1}{c}{ VARIABEL } & $\begin{array}{c}\text { Average Variance } \\
\text { Extracted (AVE) }\end{array}$ \\
\hline Online Customer Behavior & 0.786 \\
Brand Trust & 0.724 \\
Online Purchase Intention & 0.879 \\
\hline
\end{tabular}

Source: Primary data, processed 2020

The validity test is also test method comparing the root value of the square root of average variance extracted (AVE) on each construct with the correlation among other constructs contained in the model. From the results of the validity test, the result shows that that the construct has good validity.

In addition to the construct of validity test, a construct of reliability test was also measured by compositing the reliability and Alpha Cronbach's from the indicator block measuring the construct. The results of testing composite the reliability and alpha cronbach's with Smart PLS:

Table 4. The Composite Reliability and Cronbach's Alpha

\begin{tabular}{lcc}
\hline \multicolumn{1}{c}{ Variabel } & Cronbach's Alpha & Composite Reliability \\
\hline Online Customer Behavior & 0.862 & 0.917 \\
Brand Trust & 0.811 & 0.886 \\
Online Purchase Intention & 0.863 & 0.936 \\
\hline
\end{tabular}

Source: Primary data, processed 2020

The construct is reliable, if the value of composite reliability is more than 0.70 and Cronbach's alpha is more than 0.60. From the SmartPLS output results above, all constructs have the value of composite reliability above 0,70 . So it can be concluded that construct has the good reliability. The model of measurement for the test of validity and reliability, the model determination coefficient and path coefficient for equation model, as follows:

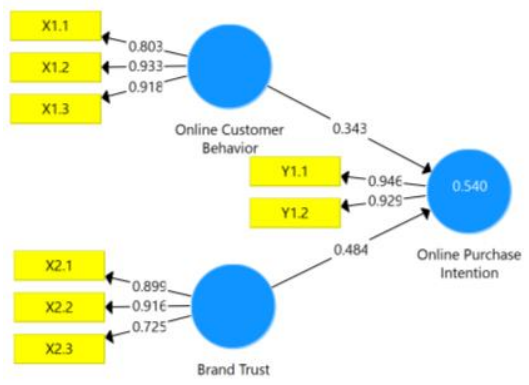

Figure 5. PLS Algorithm Results Source: Primary data, processed in 2020 
The model of structural from PLS was evaluated by using R2 for dependent variable and path coefficient value for independent variable, that is assessed for its significance which is based on the value of t-statistic for each of path. The model of structural can be seen in as follwos:

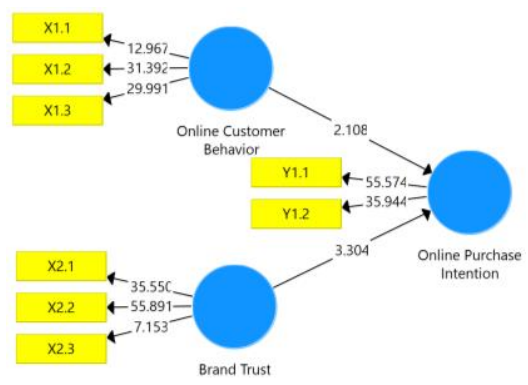

Figure 6. PLS Bootstrapping Result Source: Primary data, processed in 2020

The R2 value of each endogenous variable in this research as follwos:

Table 5. R-square

\begin{tabular}{lcc}
\hline Variabel & R Square & $\begin{array}{l}\text { R Square } \\
\text { Adjusted }\end{array}$ \\
\hline Online Purchase Intention & 0.540 & 0.531 \\
\hline
\end{tabular}

Source: Primary data, processed 2020

The value of R Square Online Purchase Intention of 0.540 shows multiple correlations (Online Customer Behavior and Brand Trust). In the next stage, a model of evaluation will be conducted through goodness of fit. The goodness of fit is known from Q-Square value. The value of Q-Square has the same meaning with coefficient of determination (R-Square) in the analysis of regression, which the higher the Q-Square, so model can be concluded more fit with data. The result of calculating the value of Q-Square value is as follows:

$$
\begin{gathered}
\text { Q-Square }=1-(1-0,540) \\
=1-0.460 \\
=0.540
\end{gathered}
$$

The results above, the value of Q-Square value is 0.540 . It shows large diversity from the data which can be explained is $54 \%$ from this research, while $46 \%$ is explained by others factors which are out of the model of the research. The model in this study can be explained that it has very good goodness of fit. 
Table 6. Path Coefficients (Mean, STDEV, t-Value)

\begin{tabular}{lcccc}
\hline Variables & Original Sample (O) & T Statistics & P Values & $\begin{array}{c}\text { Significance } \\
\text { Level }\end{array}$ \\
\hline $\begin{array}{l}\text { Online } \\
\text { Customer } \\
\text { Behavior }->\end{array}$ & 0.343 & 2.108 & 0.035 & $<0.05$ \\
$\begin{array}{l}\text { Online } \\
\text { Purchase }\end{array}$ & & & & \\
$\begin{array}{l}\text { Intention } \\
\text { Brand Trust } \\
\text {-> Online }\end{array}$ & 0.484 & 3.304 & 0.001 & \\
$\begin{array}{l}\text { Purchase } \\
\text { Intention }\end{array}$ & & & & \\
\hline Sour: Pimat & & & & \\
\hline
\end{tabular}

Source: Primary data, processed 2020

From the table above, it can be concluded that the model of measurement formed is the Equation Model:

$$
\mathrm{Y}=0.343 \mathrm{X} 1+0.484 \mathrm{X} 2
$$

$\mathrm{X} 1=$ Online Customer Behavior

$\mathrm{X} 2=$ Brand Trust

$\mathrm{Y}=$ Online Purchase Intention

It can be explained:

1) Online Customer Behavior has a positive and significant effect on Online Purchase Intention.

2) Brand Trust has a positive and significant effect on Online Purchase Intention

Based on data processing conducted by researchers, it can be used to answer the research hypothesis. The test of Hypothesis was conducted from t-value and also p-value. The hypothesis can be explained that it will be accepted, if $\mathrm{p}$-value $<0.05$ and $\mathrm{t}$-value are positive. The following are the results which is obtained in hypothesis test through the inner model:

Table 7. Hypothesis test

\begin{tabular}{|c|c|c|c|c|}
\hline Hypothesis & Effect & t-count & $P$-Value & Result \\
\hline H1 & $\begin{array}{l}\text { Online consumer behavior has } \\
\text { positive and significant effect on } \\
\text { Online Purchase Interest }\end{array}$ & 2.108 & 0.035 & Accepted \\
\hline $\mathrm{H} 2$ & $\begin{array}{l}\text { Brand trust has positive and } \\
\text { significant effect on Online Purchase } \\
\text { Interest }\end{array}$ & 3.304 & 0.001 & Accepted \\
\hline
\end{tabular}

Source: Primary data, processed 2020 
1) H1: Online consumer behavior has positive and significant effect on Hypermart Supermarket Online Purchase Interest in Tangerang City.

$\mathrm{H}_{\mathrm{o}}=$ Online consumer behavior does not has positive and significant effect on Online Purchase Interest

$\mathrm{H}_{\mathrm{a}}=$ Online consumer behavior has a positive and significant effect on Online Purchase Interest

If probability $>0.05$, then $\mathrm{H}_{\mathrm{o}}$ is accepted

If probability $<0.05$, then $\mathrm{H}_{\mathrm{o}}$ is rejected

The basis for seeing the $\mathrm{t}$ table is determined by the formula $\mathrm{df}=\mathrm{nk}$ which $\mathrm{n}=$ number of respondents and $\mathrm{k}=$ number of variables in this case 100-4 $=96$ the results obtained for $\mathrm{t}$ table are 1.98. It can be seen that online consumer behavior variable has the $t$-value count is $2.108>t$-table 1.98 and a significance level is $0.035<0.05$ or $\mathrm{H}_{\mathrm{o}}$ is rejected and $\mathrm{H}_{\mathrm{a}}$ is accepted, it can be stated that the online consumer behavior variable has a positif and significant effect on Online Purchase Interest. It means that hypothesis 1 is accepted or proven.

\section{2) H2: Brand trust has a positive and significant effect on the buying interest of Hypermart} Supermarket Online in Tangerang City

$\mathrm{H}_{\mathrm{o}}=$ Brand trust does not has positive and significant effect on Online Purchase Interest

$\mathrm{H}_{\mathrm{a}}=$ Brand trust has positive and significant effect on Online Purchase Interest

If probability $>0.05$, then $\mathrm{H}_{\mathrm{o}}$ is accepted

If probability $<0.05$, then $\mathrm{H}_{\mathrm{o}}$ is rejected

Based on Table 7 above, it can be seen that brand trust has t-value count is 2,604> t-table 1.98 and a significance level is $0.01<0.05$ or $\mathrm{H}_{\mathrm{o}}$ is rejected and $\mathrm{H}_{\mathrm{a}}$ is accepted, it can be explained that brand trust variable has a positif and significant effect on Online Purchase Interest. This means that hypothesis 2 is accepted.

\subsection{Discussions}

1) The Influence of Online Consumer Behavior on Online Purchase Intention

The dimension of Attitude to the internet on Online Consumer Behavior (X1) variable has the strongest relationship with Favorable behavioral intention on Online Purchase Interest (Y) variable. This is in accordance with the theory by Hayden Noel [8] that Consumer behavior is the behavior of individual regarding activities (purchasing and using of good and service) and how the activities can affect the individual life. The activity in question focuses on consumption activities that are carried out to spend goods and services in meeting the needs of consumers. Lee and Kim [9] stated that online consumer behavior shows consumer engagement behavior in purchasing products online.

While the dimension that has a very weak relationship is the dimension of Attitude to the internet against the Unfavorable behavioral dimension intentions. This shows that consumer behavior with the internet should be maximized to attract online purchases, but there is a reluctance to try to shop online. The dimensions of the Online Consumer Behavior variable, there are; Attitude to the internet, Computer anxiety, and Computer self efficacy. While the dimensions of Buying Interest there are; Favorable behavioral intentions and Unfavorable behavioral intentions. 
The results are in accordance with previous researchs conducted by [10], [15], [16], [17], [18], [19], [20], [21], that online consumer behavior variable has a positif and significant effect on Online Purchase Intention.

\section{2) The influence of Brand Trust on Online Purchase Intention}

The dimension of The system used on Brand Trust (X2) is the strongest relationship variable with Unfavorable behavioral intentions dimension on the Online Purchase Intention variable (Y). The theory from Keller that a brand is more than product because it has dimension which are able to distinguish the design of similar products from other competitors [11]. In other words, a brand functions as an identity that differentiates between products, be it similar or different products. Brand trust is something that is trusted and stored as a consumer's memory because it has an important meaning.

Meanwhile, the dimension that has a very weak relationship is perceived risk dimension in brand trust $(\mathrm{X} 2)$ variable on favorable behavioral intention on the online purchase intention $(\mathrm{Y})$ variable. This shows that Hypermart is still lack of convincing consumers of the risks that will be received when making online purchase transactions.The dimensions of Brand Trust, there are; the system used, reputation, and perceived risk. While dimensions of Buying Interest Online, there are; Favorable behavioral intention and Unfavorable behavioral intentions. The results of this study are in accordance with previous researchs conducted by [22], [23], [24], [25], [26], [27], and [28] that Brand Trust variable has a positif and significant effect on Online Purchase Intention.

\section{Conclusions and Suggestions}

\subsection{Conclusions}

The conclusions based on the results are as follows:

1) This research proves that the behaviour of online consumer has positif and significant effect on Online Purchase Interest. The Consumer tends to look for shop online and information on familiar brands, both online shops and products. Online consumer behavior shows consumer engagement behavior in purchasing products online.

2) Brand Trust has a significant positive effect on Online Purchase Interest. Brand trust is something that is trusted and remained in the memory of consumers because it has an important meaning. The brand is more than just product because it has dimension that can distinguish the same similar product designs from other competitors. In other words, a brand functions as an identity that differentiates between products, be it similar or different products.

\subsection{Suggestions}

The suggestions which can given for interested parties are:

1) For academic

For the future research is suggested to examine the other variables related in examining Online Purchase Interest in physical store which also have online stores. It is very rare for an existing physical store to participate in the online shopping business with such success as physical 
store as a main business. Because the behaviour of consumer will not be the same, physical store where consumers are accustomed to visiting the store directly with an online store, which in fact consumers simply use a smartphone when shopping. This side is what determines and differentiates physical stores which also have online stores.

2) Practical

Having both physical store and the store of online should be real advantage for physical stores. Existing physical stores are important assets by building Online Purchase Interest to distribute to the new product and service such as consumer of online shopping. Of course, the introduction of online shopping owned by a physical store must be intense or sustainable so that consumers are more familiar with these new products or services.

\section{References}

[1] A. Leeraphong and B. Papasratorn, "S-Commerce Transactions and Business Models in Southeast Asia: A Case Study in Thailand," KnE Soc. Sci., vol. 3, no. 1, p. 65, 2018.

[2] Allen, "Analysis of Trends and Challenges in the Indonesian Labor Market," Asian Dev. Bank Pap. Indones., no. 16, pp. 1-38, 2016.

[3] L. L. (Luke) Chiang and C. S. Yang, "Does country-of-origin brand personality generate retail customer lifetime value? A Big Data analytics approach,” Technol. Forecast. Soc. Change, vol. 130, no. January, pp. 177-187, 2018.

[4] J. Ding, W. Song, and D. Zhang, "M Odeling and a Nalysis of M Obile P Ush N Otification," vol. 2, no. 4, pp. 52-64, 2014.

[5] Kotler and Keller, Manajemen Pemasaran, Second. Erlangga, 2013.

[6] J. Ahn and K. J. Back, “Antecedents and consequences of customer brand engagement in integrated resorts," Int. J. Hosp. Manag., vol. 75, no. May, pp. 144-152, 2018.

[7] and S. Mamang, Perilaku Konsumen. Yogyakarta: Andi, 2013.

[8] and K. Keller, Marketing Management, 14th ed. Jakarta: PT. Indeks Kelompok Gramedia, 2012.

[9] H. Noel, Consumer Behaviour. Switzerland: Ava Publishing SA, 2009.

[10] Y. Lee and H. Y. Kim, "Consumer need for mobile app atmospherics and its relationships to shopper responses," J. Retail. Consum. Serv., vol. 51, no. October 2017, pp. 437-442, 2019.

[11] A. M. Cazan, E. Cocorade, and C. I. Maican, "Computer anxiety and attitudes towards the computer and the internet with Romanian high-school and university students," Comput. Human Behav., vol. 55, pp. 258-267, 2016.

[12] Keller, Strategic Brand Management, 4th ed. Harlow: Pearson, 2013.

[13] D. Priansa, Perilaku Konsumen dalam Persaingan Bisnis Kontemporer. Bandung: ALFABETA, 2017.

[14] F. Augusty, Metode Penelitian Manajemen: Pedoman Penelitian untuk skripsi, Tesis dan Disertai Ilmu Manajemen. Semarang: Universitas Dipenogoro, 2006.

[15] A. Rahman, "Brand Image, eWOM, Trust and Online Purchase Intention of Digital Products among Malaysian Consumers," J. Xi'an Univ. Archit. Technol., vol. XII, no. III, pp. 4935-4946, 2020.

[16] B. Han, M. Kim, and J. Lee, "Exploring consumer attitudes and purchasing intentions of crossborder online shopping in Korea," J. Korea Trade, vol. 22, no. 2, pp. 86-104, 2018.

[17] B. J. G. Shivani, Shweta., "Mapping of Online Shopping behaviour: A Dark Triad Approach," Indian J. Commer. Manag. Stud., vol. IX, no. 2, p. 78, 2018.

[18] A. P. Muhammad, "Analisis Perilaku Konsumen Generasi Milenial dalam Keputusan Pembleian Online dengan Online Trust sebagai Variabel Intervening (Survey pada Toko Online Lazada di Kota Padang) (Doctoral dissertation, Universitas Andalas).," pp. 2015-2017, 2018.

[19] A. Bhatti and S. Ur Rehman, "Perceived Benefits and Perceived Risks Effect on Online Shopping 
Behavior With the Mediating Role of Consumer Purchase Intention in Pakistan," Int. J. Manag. Stud., vol. 26, no. 1, pp. 33-54, 2020.

[20] J. Silva, J. C. Pinho, A. Soares, and E. Sá, “Antecedents of online purchase intention and behaviour: Uncovering unobserved heterogeneity,” J. Bus. Econ. Manag., vol. 20, no. 1, pp. 131-148, 2019.

[21] Y. Liu, X. Luo, and Y. Cao, "Investigating the influence of online interpersonal interaction on purchase intention based on stimulus-organism-reaction model," Human-centric Comput. Inf. Sci., vol. 8 , no. $1,2018$.

[22] M. Tedeschi, G. Galli, and M. C. Martini, "On and off-line purchase intention: the role of brand trust as moderator of risk perception," J. Emerg. Trends Mark. Manag., vol. 1, no. 1, pp. 194-203, 2017.

[23] M. Wijaya, E., Semuel, H., \& Adiwijaya, "Pengaruh Celebrity Endorsement Di Media Sosial terhadap Purchase Intention dengan Brand Image dan Brand Trust sebagai Variabel Intervening pada Produk Fashion," Petra Bus. Manag. Rev., vol. 5, no. 1, 2019.

[24] N. S. A. Rani and Z. Suradi, "International brand vs. local brand: An evaluation of brand trust, brand reputation, customer satisfaction and purchase intention of Malaysian customers," J. Bus. Retail Manag. Res., vol. 11, no. 3, pp. 179-185, 2017.

[25] M. Bhandari and S. Rodgers, "What does the brand say? Effects of brand feedback to negative eWOM on brand trust and purchase intentions," Int. J. Advert., vol. 37, no. 1, pp. 125-141, 2018.

[26] Y. J. Jung and J. Kim, "Facebook marketing for fashion apparel brands: Effect of other consumers' postings and type of brand comment on brand trust and purchase intention," J. Glob. Fash. Mark., vol. 7, no. 3, pp. 196-210, 2016.

[27] M. A. Khan, R. Panditharathna, and D. Bamber, "Online store brand experience impacting on online brand trust and online repurchase intention: The moderating role of online brand attachment," Eur. $J$. Manag. Mark. Stud., vol. 5, no. 1, pp. 128-162, 2020.

[28] M. Hendra, "Model Kepercayaan Merek: Analisa Perilaku Konsumsen Secara Online, Kepuasan Konsumen Terhadap Minat Beli Ulang (Studi Kasus Supermarket Hypermart di Kota Tangerang)," Thesis, 2019. 